\title{
Tayloring Surface Properties of Rare Earth Magnesium Alloy for Biomedical Application Induced by Laser Processing
}

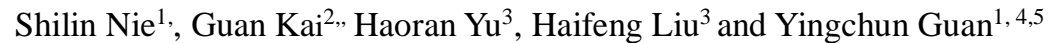 \\ ${ }^{1}$ School of Mechanical Engineering \& Automation, Beihang University, Xueyuan Road, Beijing 100191, China \\ E-mail: guanyingchun@buaa.edu.cn \\ ${ }^{2}$ Department Of Oncology, Center Of Excellence. Hefei BOE Hospital Co., Ltd, Hefei, Anhui, 230013, China \\ ${ }^{3}$ School of Biological Science \& Medical Engineering, Beihang University, Xueyuan Road, Beijing 100191, \\ China,E-mail: haifengliu@buaa.edu.cn \\ ${ }^{4}$ National Engineering Laboratory of Additive Manufacturing for Large Metallic Components, \\ Beihang University, Xueyuan Road, Beijing 100191, China \\ ${ }^{5}$ Hefei Innovation Research Institute of Beihang University, Xinzhan Hi-tech District, Anhui, 230013, China \\ Shilin Nie and Guan Kai contributed equally to this work
}

\begin{abstract}
Magnesium alloy has attracted much attention as biodegradable material for medical devices in recent years. However, poor corrosion resistance is the main problem to limit practical applications. High degradation rate will cause fast increase in $\mathrm{pH}$, while the large release of ions into the medium can lead to cytotoxicity. In this work, we demonstrate the capability of laser surface modification for corrosion resistance of Mg-Gd-Ca alloy to avoid rapid degradation, which helps to enhance the biocompatibility. Microstructure of both as-received surface and laser-modified surface were analyzed carefully by Scanning Electron Microscopy and X-ray Diffraction. Electrochemical corrosion behavior and immersion test was investigated in order to examine the degradable behavior of lasermodified Mg-Gd-Ca alloy. The enhanced corrosion resistance was found to be caused by the combined effect of secondary phase dissolution and galvanic corrosion reduction in the laser-modified zone. Results of direct cell culturing suggested that the laser-modified surface exhibited good cell adhesion property, spreading performance and proliferation capacity. Special attention was focused on the influence of laser-induced patterns on cell adhesion and growth process.

DOI: 10.2961/jlmn.2018.03.0014
\end{abstract}

Keywords: laser surface modification, biodegradable magnesium alloy, microstructure, corrosion resistance, biocompatibility

\section{Introduction}

Magnesium alloy, with high specific strength and low density, is currently one of the most potential biomedical structural material. However, the poor corrosion resistance along with activity chemical properties limits its application scope[1-4]. The rapid corrosion rate of magnesium alloys in vivo may lead to a premature loss of structural integrity[5,6]. Furthermore, $\mathrm{H}_{2}$ bubbles and high $\mathrm{pH}$ environment caused by corrosion of magnesium alloy may lead to tissue necrosis.

A simple and useful way to achieve better corrosion resistance of magnesium alloy is surface modification, such as anodic oxidation, micro-arc oxidation, organic coating, thermal spraying, physical vapor deposition[7-12], which are expensive or harmful for environment. In recent years, laser surface processing has been widely used in aerospace, automobile, and electronics device, showing the advantages of without adding alloy elements, natural metallurgical bonding interface[13-16]. So far, laser surface treatment has been proven effective which can enhance the corrosion resistance of magnesium alloys. Koutsomichalis et al.[15] obtained a better corrosion resistance of AZ31B magnesium alloy in a $\mathrm{NaCl}$ solution using excimer laser treatment. Khadka et al.[17] reported that the bio-wettability improvement of WE54 Mg alloys induced by 500W Nd:YAG pulsed laser was probably associated with changes in microstructure and surface morphology after laser treatment.
Majumdar et al.[18] reported that the pitting corrosion resistance of MEZ magnesium alloy was enhanced by laser surface melting. Abbas et al.[19], Guo et al.[20] and Gao et al.[21]also obtained similar enhancement of corrosion resistance of AZ31, AZ61, AZ91 and WE43 Mg-alloys after laser surface melting. Guan et al.[22,23] reported that the $\beta$-Mg17Al12 phases refined and $\mathrm{Al}$ concentration increased in AZ91 Mg alloy after laser melting, causing a decrease of corrosion rate by $70 \%$ in simulated-modified body fluid at $37^{\circ} \mathrm{C}$. Florian et al.[24] studied both corrosion resistance and bio-wettability of AZ31B alloy in simulated-modified body fluid. The laser irradiated sample revealed a contact angle below $10^{\circ}$ and a reduction by $50 \%$ in weight loss rate after immersion. These improvements are proved to be due to phase evolution and alloying elements enrichment. Nevertheless, few report has been worked on combination of different laser surface treatments. Especially the in vitro biocompatibility of laser-treated Mg alloy needs to be detected.

In present paper, hot extruded Mg-6Gd-0.6Ca alloy was researched. The main purpose of the study was to employ the laser surface processing to modify the surface of Mg-6Gd-0.6Ca alloy for biomedical application. Microstructural changes subjected to laser surface processing were examined, and its effects on corrosion behavior and in vitro biocompatibility were investigated in detail. The regulation of cell growth was managed by increasing local cor- 
rosion rate of textured grooves area.

\section{Experimental procedures}

\subsection{Material}

The rare earth magnesium alloy used in this study was Mg-6Gd-0.6Ca alloy. The Mg-6Gd-0.6Ca alloy was hot extruded into bars with a diameter of $9.2 \mathrm{~mm}$, and then cut into $4 \mathrm{~mm}$ thick cylindrical slices perpendicular to the extrusion direction. All slices were polished with SiC abrasive paper (from 600 to 2000 grit) and washed with ethanol

\subsection{Laser processing}

Two lasers were chosen to carry out different surface modifications on the slices. To improve overall corrosion resistance, a continuous wave fiber laser (wavelength = $1060 \mathrm{~nm}$, spot size $=100 \mu \mathrm{m}$ ) was chosen for laser surface melting. The optimized average power was $80 \mathrm{~W}$, and the optimized scanning parameters were scanning speed of 70 $\mathrm{mm} / \mathrm{s}$ and overlap of $40 \%$. Laser beam scanned twice on the whole end surface of cylindrical slice. Argon gas was used to prevent oxidation reaction of samples during laser melting processing.

After laser melting, grooves were textured on the melted surface via another pulsed Nd-YAG laser (wavelength = $1064 \mathrm{~nm}$, spot size $=30 \mu \mathrm{m}$, pulse width $=600 \mathrm{ps}$ ). The optimized laser parameters were power of $7 \mathrm{~W}$ and frequency of $100 \mathrm{kHz}$. The laser beam scanned five times at the speed of $100 \mathrm{~mm} / \mathrm{s}$, and optimized grooves' parameters were spacing of $400 \mu \mathrm{m}$, width of $30 \mu \mathrm{m}$ and depth of 50 $\mu \mathrm{m}$.

\subsection{Surface characterization}

The surface morphology was measured by a 3D laser scanning confocal microscope. The microstructure and phase evolution of slices were observed by optical microscopy and scanning electron microscopy energy dispersive spectrometer (EDS). X-ray diffraction (XRD) was also used to analyze phase composition.

\subsection{Corrosion tests}

Corrosion resistance of samples was examined by electrochemical method and immersion test. All corrosion tests were conducted in Hank's Balanced Salt Solution (HBSS) as modified simulated body fluid maintained at a temperature of $37{ }^{\circ} \mathrm{C}$. The samples were sealed with silicone rubble, and exposed area was $0.665 \mathrm{~cm}^{2}$. The chemical composition of HBSS is shown in Table 1.

Table 1 chemical composition of HBSS

\begin{tabular}{ccc}
\hline \multicolumn{3}{c}{ Composition (g/L) } \\
\hline $\mathrm{NaCl}$ & $\mathrm{KCl}$ & $\mathrm{CaCl}_{2}$ \\
8 & 0.4 & 0.14 \\
\hline $\mathrm{NaHCO}_{3}$ & $\mathrm{C}_{6} \mathrm{H}_{6} \mathrm{O}_{6}$ & $\mathrm{MgCl}_{2} \cdot 6 \mathrm{H}_{2} \mathrm{O}$ \\
0.35 & 1 & 0.1 \\
\hline $\mathrm{MgSO}_{4} \bullet 7 \mathrm{H}_{2} \mathrm{O}$ & $\mathrm{KH}_{2} \mathrm{PO}_{4}$ & $\mathrm{Na}_{2} \mathrm{HPO}_{4} \bullet 12 \mathrm{H}_{2} \mathrm{O}$ \\
0.06 & 0.06 & 0.06 \\
\hline
\end{tabular}

Potentiodynamic polarisation test was used to evaluate the instant corrosion resistance of samples via an electrochemical workstation. The samples worked as the working electrode in a three-electrode system. The scan rate of Tafel curves was set to $0.1 \mathrm{mV} / \mathrm{s}$.
The corrosion behavior of Mg-6Gd-0.6Ca alloy was observed under immersion conditions at a microstructural level. The sample of Mg-6Gd-0.6Ca alloy were prepared by mounting in the metallographic resin and polishing the surface down $2 \mu \mathrm{m}$ to reveal a flat surface and to remove oils and oxides from the surface. The surface was etched using $0.5 \%$ picric acid solution to reveal the microstructure. The sample was then flexed to a stage in a rubble tank using double-sided tape. And $20 \mathrm{~mL}$ of HBSS was added to the tank so that the sample was immersed. The lens of microscope was manoeuvred to the right height so that imaging of the microstructure under the HBSS can be achieved. The duration of experiments were $8 \mathrm{~h}$. A schematic of the microscope set-up is given in Fig.1.

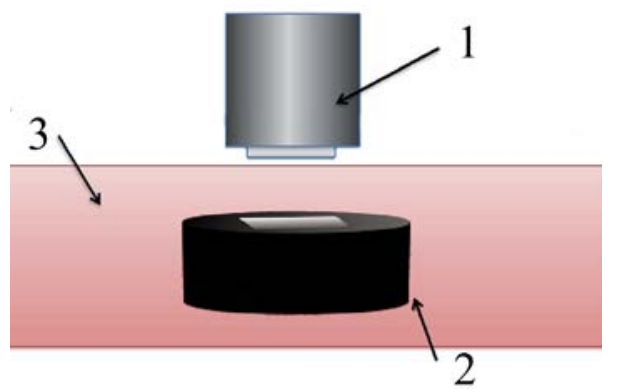

Fig.1 Schematic diagram of in situ optical microscopy configuration: 1) optical microscope lens; 2) sample mounted in metallographic resin; 3) HBSS

\subsection{Cell culture}

A mouse embryo osteoblast precursor (MC3T3-E1) cell line was used to study the biocompatibility of all the samples in vitro. MC3T3-E1 cells were culture in Dulbecco's modified Eagle's medium (DMEM) supplemented with $10 \%$ fetal bovine serum (FBS), $100 \mathrm{U} / \mathrm{ml}$ penicillin and $100 \mu \mathrm{g} / \mathrm{mL}$ streptomycin in a $37{ }^{\circ} \mathrm{C}$, humidified $5 \% \mathrm{CO}_{2}$ environment. Before cell seeding, the samples had been washed by ultrasonic cleaning with ethanol and sterilized under ultraviolet irradiation for 24h. Generation 3 and 4 cells were used for all cell culture, seeded at a density of $1.0 \times 10^{5}$ cells $/ \mathrm{cm}^{2}$ per specimen.

\subsection{Cell viability and morphology}

After the culture assay of $12 \mathrm{~h}, 24 \mathrm{~h}$ and $48 \mathrm{~h}$, the cell viability and morphology among groups were determined. CCK-8 assay was developed to evaluate the cell viability by measuring the optical density (OD) at $450 \mathrm{~nm}$ according the kit instruction. The cell morphology was detected by SEM. The cell-seeded samples were rinsed with PBS and fixed in paraformaldehyde for $30 \mathrm{~min}$. Then the samples were rinsed again with PBS and dehydrated using graded ethanol, followed by vacuum-drying. Finally, the samples sprayed gold were observed by SEM.

\section{Results and discussion}

\subsection{Surface morphology}

Fig. 2 shows the optical micrograph and profilometry of the as-received and laser processed samples. The surface roughness $\left(R_{a}\right)$ of the as-received sample was $2.03 \mu \mathrm{m}$. And $R_{a}$ of processed surface rose to $3.04 \mu \mathrm{m}$ after laser melting. As shown in Fig.2 (c), the textured grooves were spacing of $400 \mu \mathrm{m}$, width of $40 \mu \mathrm{m}$ and depth of $40 \mu \mathrm{m}$. 


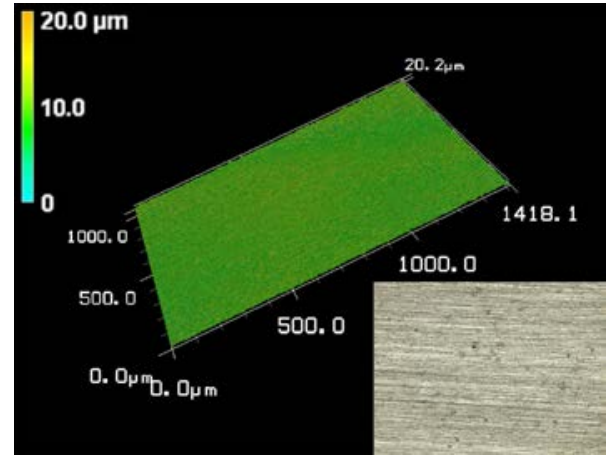

(a)

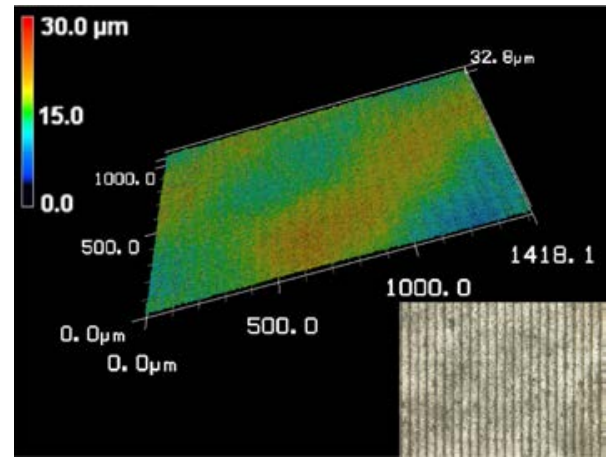

(b)

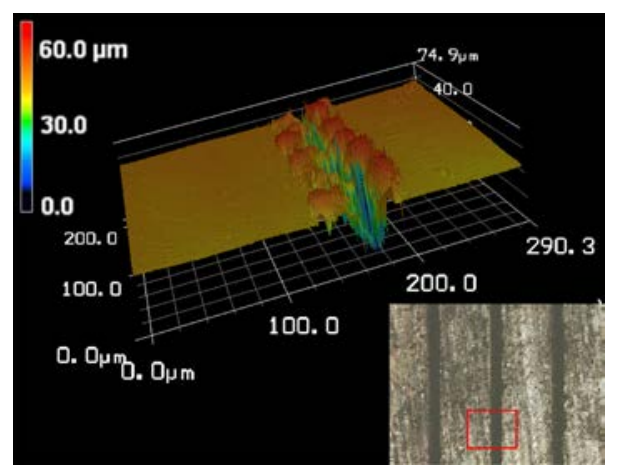

(c)

Fig.2 surface profiles of Mg-6Gd-0.6Ca alloy samples: (a) asreceived; (b) laser melted; (c) laser melted \& textured

\subsection{Microstructure and phase evolution}

Fig.3 shows the microstructure of substrate, melted layer and textured groove. The microstructure in the asreceived substrate mainly consisted of $\alpha-\mathrm{Mg}$ phase, which grain size is $25 \pm 13 \mu \mathrm{m}$. And the bright $\mathrm{Mg} 5 \mathrm{Gd}$ particles were observed as second phase with zonal distribution in extrusion direction[25,26], as shown in the detail view of Fig.3. As a result of laser melting, a melted layer of 120 $\mu \mathrm{m}$ thick was formed over the sample surface. A distinct change was found in the microstructure of melted layer. The solidification microstructure of melted layer consisted of columnar grains of $\alpha-\mathrm{Mg}$ phase with a grain size of 30 to $150 \mu \mathrm{m}[26-28]$. At the bottom of melted layer, the grain growth of re-solidified microstructure was discovered vertical from the substrate. The chemical compositions of melted layer and as-received substrate were quantitatively analyzed by EDS measurement, which were listed in Table.2. In as-received substrate, Gd content in $\beta$ phase was almost nine times of that in $\alpha-\mathrm{Mg}$ matrix. Moreover, no $\beta$ phase was observed in melted layer, as shown in Fig.3 and Fig.4. With the disappearance of Mg5Gd particles, Gd con- tent in $\alpha-\mathrm{Mg}$ matrix rose by $13.6 \%$ compared to that in asreceived $\alpha$-Mg phase. On the other hand, the sizes of textured groove in Fig. 3 were width of $40 \mu \mathrm{m}$ and depth of about $45 \mu \mathrm{m}$, which were close with results of laser scanning confocal microscope. The XRD results in Fig.4 also showed that the melted layer after laser texturing has same phase constitute as that before laser surface texturing. It indicated that laser surface texturing does not affect on the metallurgical microstructure of Mg alloy.

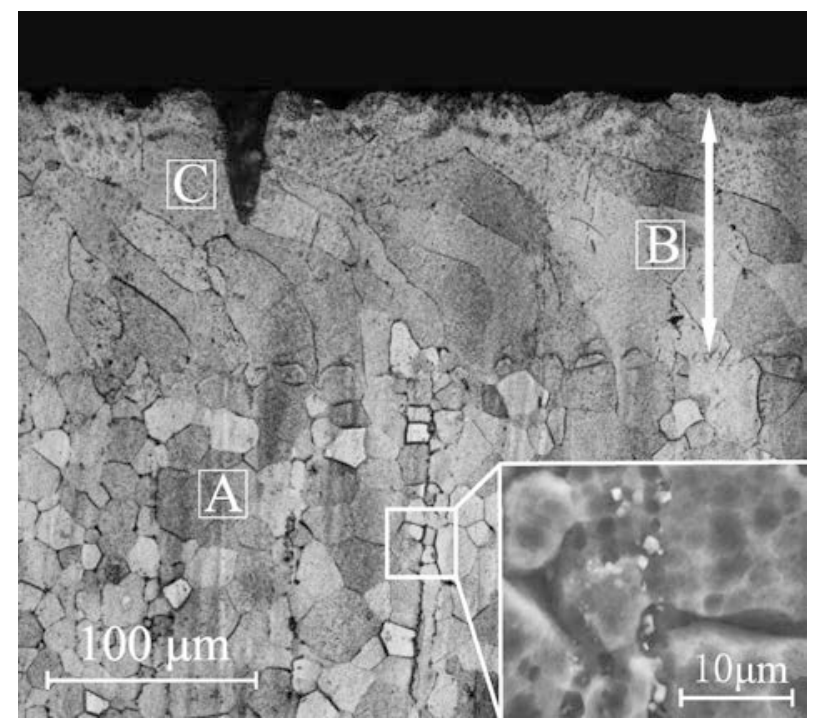

Fig.3 microstructure of laser treated Mg-6Gd-0.6Ca alloy: A, substrate; $\mathrm{B}$, melted layer; $\mathrm{C}$, textured groove

Table.2 Chemical composition of different phases investigated

\begin{tabular}{cccc}
\multicolumn{4}{c}{ (wt\%) } \\
\hline Nominal composition & Gd & Ca & $\mathrm{Mg}$ \\
\hline$\alpha$-phase in substract & 3.2 & 0.4 & Balance \\
$\beta$-phase & 42.9 & 3.4 & Balance \\
$\alpha$-phase in melted layer & 8.7 & 1.1 & Balance \\
\hline
\end{tabular}

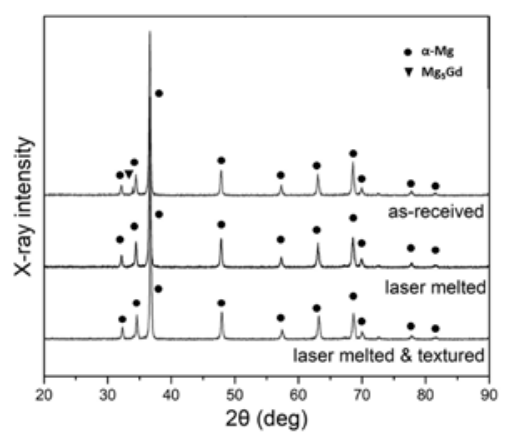

Fig.4 XRD patterns for the Mg-6Gd-0.6Ca alloys after different treatment

The main reason for phases change can be explained by temperature gradient and cooling rate which are proved to have an important influence on solidification microstructure. During the laser surface melting, the surface temperature of laser irradiated area instantly rose up to the melting point of Mg-6Gd-0.6Ca alloy. After laser beam left, the surface temperature rapidly dropped due to self-quenching, which caused high temperature gradient in the melted layer. The melted equiaxed grains recrystallized and tended to 
grew into columnar grains along the orientation of temperature gradient[29]. Meanwhile, rapid cooling rate may also cause the solidification of the supersaturated solid solution matrix, with little dendritic segregation[30]. The $\beta$ phase Mg5Gd particles in the melted layer decreased, resulting in the enrichment of Gd in $\alpha$-Mg phase.

\subsection{Corrosion behavior}

Fig. 5 shows the Tafel curves of as-received and laser treated samples in HBSS. Corrosion potential (Ecorr) and corrosion current density (icorr) were listed in Table.3, which were calculated from the intersection of cathode and anode polarization curve in the respective curves. As known in Table.3, the as-received sample exhibited lowest $\mathrm{E}_{\text {corr }}$ value (-1.591 V). The $\mathrm{E}_{\text {corr }}$ of laser melted sample had a visible increase by $0.025 \mathrm{~V}$ than that of the as-received sample. Moreover, the $\mathrm{i}_{\text {corr }}$ of laser melted sample dropped to only $7.89 \%$ of as-received sample's. It indicated that corrosion resistance of Mg-6Gd-0.6Ca alloy surface had been enhanced after laser surface melting.

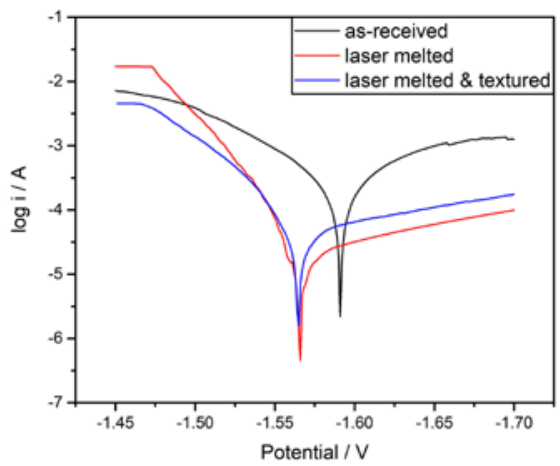

Fig.5 Tafel curves for Mg-6Gd-0.6Ca alloys in HBSS

$\mathrm{Mg}_{5} \mathrm{Gd}$ particles distributed in the boundaries of $\alpha-\mathrm{Mg}$ matrix acted as a galvanic cathode in the corrosive medium, forming a galvanic couple with $\alpha-\mathrm{Mg}$ matrix. It leaded to a higher corrosion rate of $\alpha-\mathrm{Mg}$ matrix[31,32]. Due to the dissolution of $\mathrm{Mg}_{5} \mathrm{Gd}$ particles after laser melting, the grains distribution of melted layer became more uniform. Micro galvanic corrosion activity reduced significantly which was supported by the change of $i_{\text {corr }}$.

Table.3 $\mathrm{E}_{\text {corr }}$ and $\mathrm{i}_{\text {corr }}$ for Mg-6Gd-0.6Ca alloys in HBSS

\begin{tabular}{ccc}
\hline & $\mathrm{E}_{\text {corr }}(\mathrm{V})$ & $\mathrm{i}_{\text {corr }}\left(\mathrm{mA} / \mathrm{cm}^{2}\right)$ \\
\hline As-received & -1.591 & 0.436 \\
Laser melted & -1.566 & 0.034 \\
Laser melted \& textured & -1.565 & 0.071 \\
\hline
\end{tabular}

In addition, there was almost no difference in the $E_{\text {corr }}$ between the laser melted sample and laser textured one. $\mathrm{I}_{\text {corr }}$ of melted layer had more than doubled due to the introduction of textured grooves. The corrosion behavior of melted layer had no change after laser texturing. Textured grooves increased local area exposed to HBSS, which makes corrosion current increase. However, the $\mathrm{i}_{\text {corr }}$ of laser melted and textured sample $\left(0.071 \mathrm{~mA} / \mathrm{cm}^{2}\right)$ was still far lower than that of as-received sample $\left(0.436 \mathrm{~mA} / \mathrm{cm}^{2}\right)$.

Fig.6 (a)-(e) show the microstructure of as-received Mg-6Gd-0.6Ca alloy taken at $2 \mathrm{~h}$ intervals during in situ immersion in HBSS. A corrosion feature developed within the microstructure of Mg-6Gd-0.6Ca and grew in size with time towards the same orientation. As shown in Fig.6 (a), the pitting corrosion was the most obvious corrosion activity in the early stages, which progressed preferentially in the $\alpha$-Mg phases. After immersion for 6 h, amount of corrosion pits increased and the corrosion rate accelerated. The early corrosion pits extended to deeper holes. At the end of in situ immersion test, it was also noticed that the corrosion points presented discontinuous zonal distribution across the $\alpha$-Mg phases along the same orientation, which accelerated the corrosion rate of Mg-6Gd-0.6Ca alloy surface.

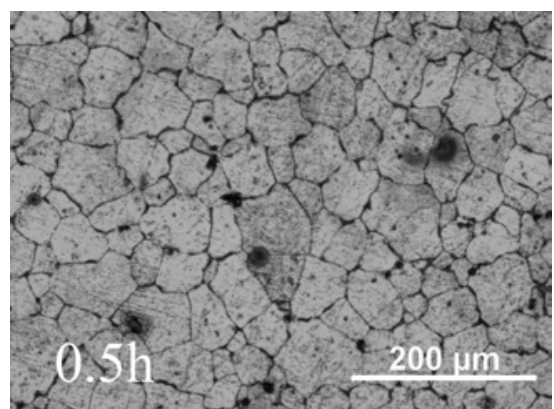

(a)

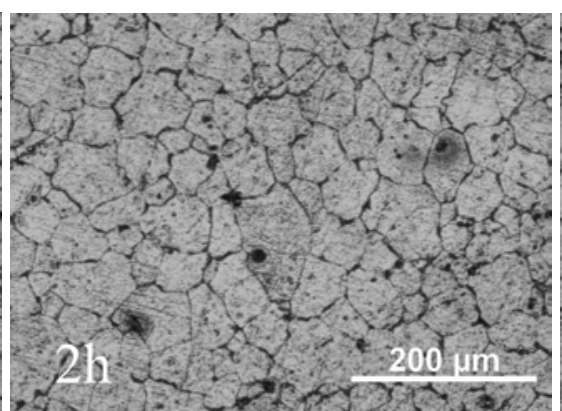

(b)

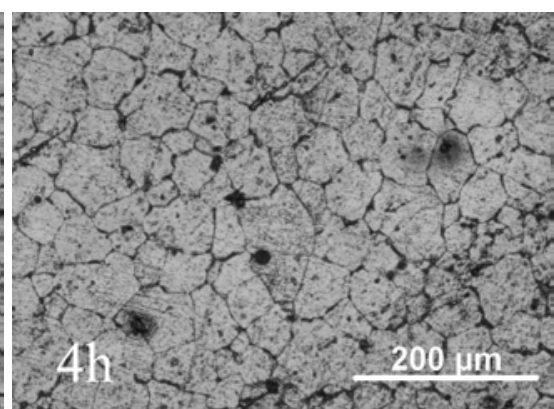

(c)

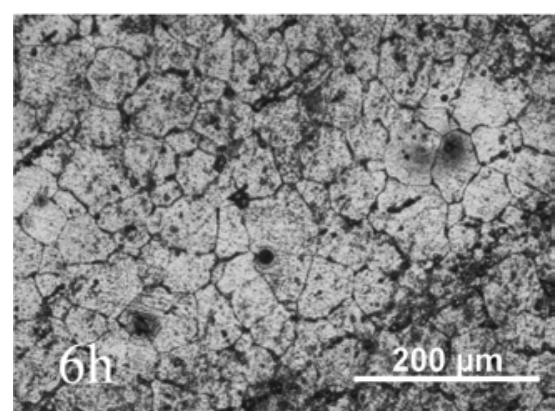

(d)

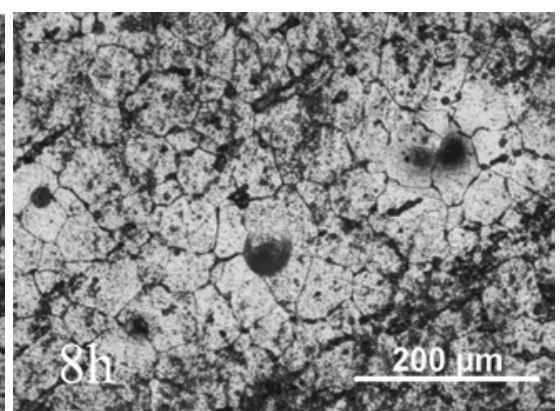

(e)

Fig.6 Optical microscope images of Mg-6Gd-0.6Ca alloy taken in situ under immersion conditions 
Fig.7 shows the trend of weight loss versus immersion time for different Mg-6Gd-0.6Ca samples. The corrosion rate of as-received samples was much higher than other two groups, which was consistent with the electrochemical results. The corrosion rate of laser melted and textured samples was very close to that of the laser melted ones in the early stages, and became higher after 36h. It suggested that laser surface melting has substantial improvements of the corrosion resistance under immersion conditions.

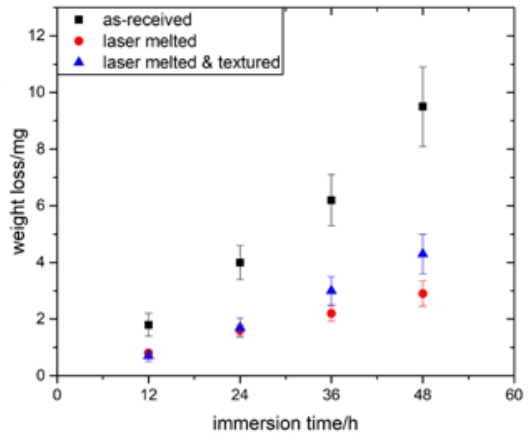

Fig.7 Weight loss versus time for Mg-6Gd-0.6Ca alloys in HBSS

\subsection{In vitro biocompatibility}

Fig.8 shows the average OD values among different groups after incubation time of $12 \mathrm{~h}, 24 \mathrm{~h}$ and $48 \mathrm{~h}$, which directly indicates the viability of cells inoculated on Mg6Gd-0.6Ca alloy surfaces. The OD values of as-received samples stayed in a low level during whole culture process.
While the OD values of other two groups was 3 to 5 times higher than that of as-received group. The cell morphology in Fig.9 also shows the similar results. As shown in Fig.9 (a)-(c), few cells survived on the surface of the as-received samples. The cells remained mostly existed as single cell, exhibiting negative cell viability. Conversely, MC3T3-E1 cells performed good adhesion and proliferation on the surfaces other two groups. Most cells joined together as cell mass and spreaded outward with filopodia in Fig.9 (d)(i). Moreover, in laser melted and textured group, cells tended to gather between two grooves instead of in or over grooves.

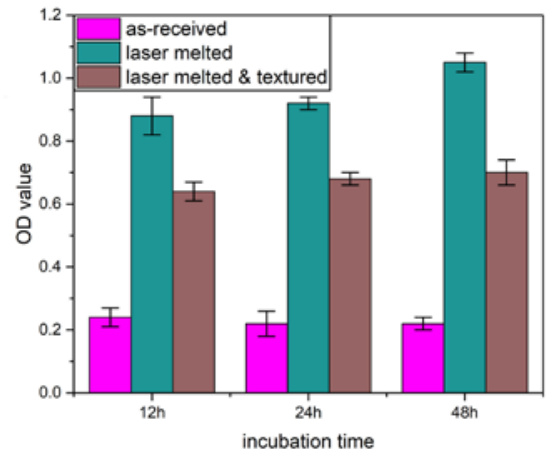

Fig.8 Cell proliferation on different sample surfaces evaluated by CCK-8 test

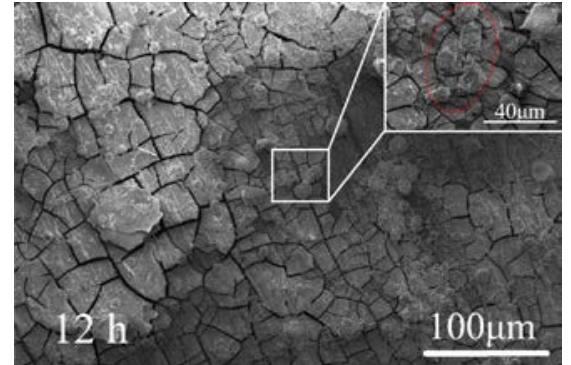

(a)

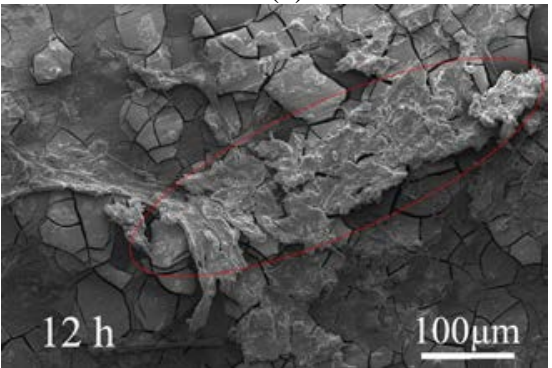

(d)

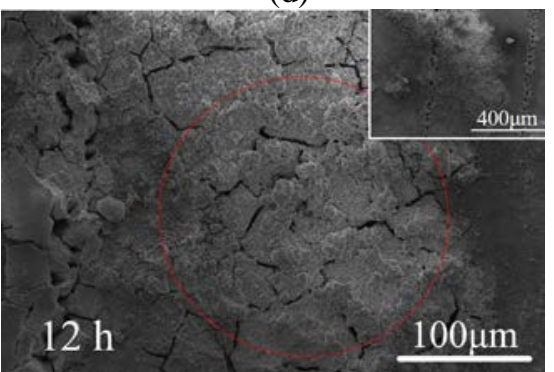

(g)

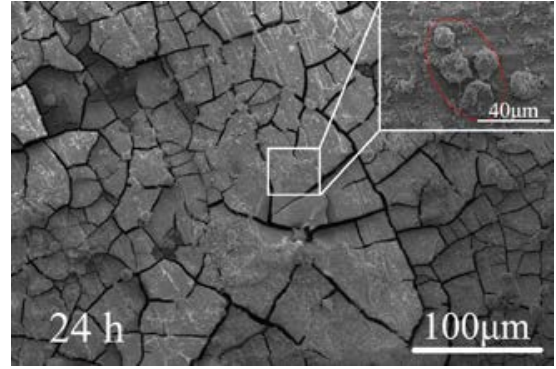

(b)

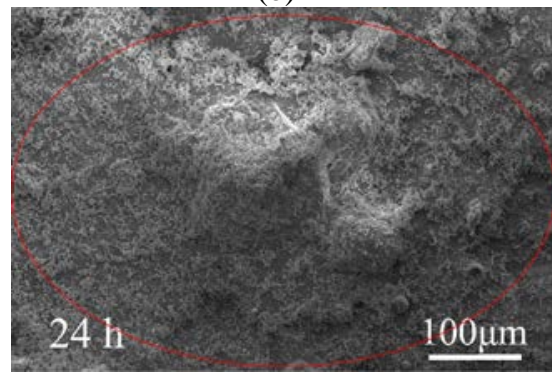

(e)

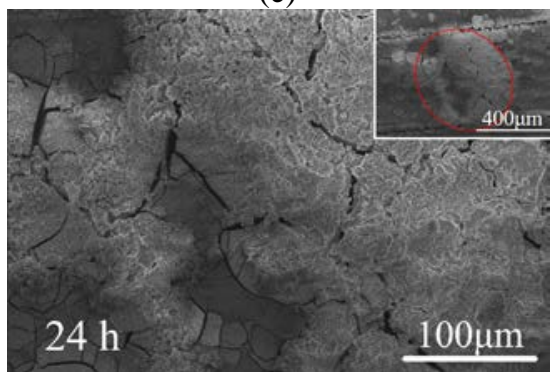

(h)

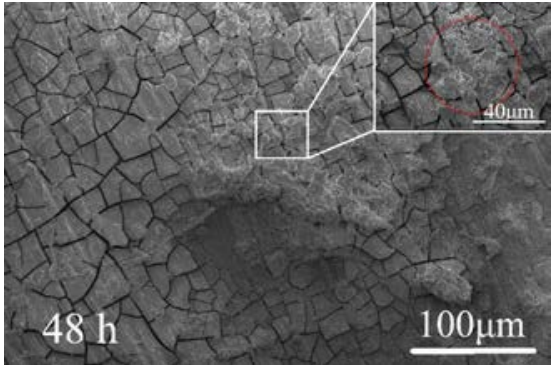

(c)

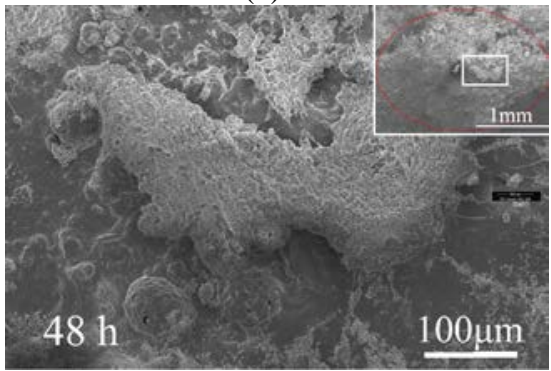

(f)

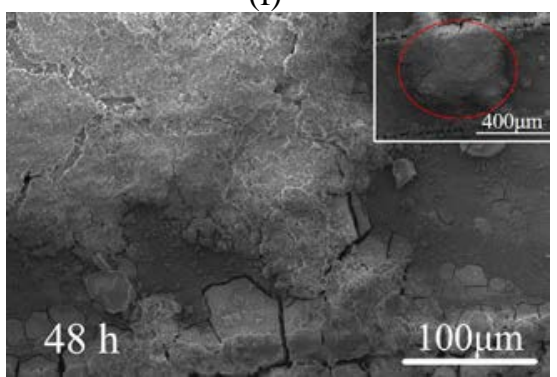

(i)

Fig.9 SEM images of cells cultured on Mg-6Gd-0.6Ca alloy surfaces: (a)-(c) as-received; (d)-(f) laser melted; (g)-(i) laser melted \&textured. Ps: the areas of cell growth were marked in red circles. 
The high $\mathrm{pH}$ caused by rapid corrosion rate of asreceived sample could be the major factor to interfere the attach and growth of MC3T3-E1[33,34]. Benefited from lower corrosion rate, biocompatibility of Mg-6Gd-0.6Ca alloy was significantly enhanced after the treatment of lasersurface melting. Furthermore, in the laser melted and texured group, the textured grooves sightly increased the local corrosion rate, causing that cells were limited between textured grooves and cell viability generally remained high.

\section{Conclusion}

In present paper, laser surface treatment including laser surface melting and laser surface texturing were implemented on Mg-6Gd-0.6 alloy. The effects of laser surface treatment on the microstruction evolution, corrosion behavior and in vitro compatibility were analyzed.

1) The microstructure of as-received Mg-6Gd-0.6 alloy was composed of $\alpha-\mathrm{Mg}$ phase and $\beta-\mathrm{Mg} 5 \mathrm{Gd}$ phase with zonal distribution along extrusion direction. After laser surface melting, the microstructure of melted zone was composed of only $\alpha-\mathrm{Mg}$ phase, and $\beta$ phase was dissolved in $\alpha$-Mg matrix.

2) The main corrosion type of Mg-6Gd-0.6Ca in HBSS is pitting corrosion, which occurred preferentially in the $\alpha$ Mg phases. The corrosion rate of Mg-6Gd-0.6Ca alloy surface had been visibly decreased after laser surface melting, because of the dissolution of $\beta$ phase and reduction of micro galvanic couple.

3) Few cells survived on as-received sample surfaces during culture process the because of poor corrosion resistance. Cells cultured on laser melted groups exhibited a better adhesion and proliferation. In laser melted and textured group, cell mess tended to grow between grooves.

\section{Acknowledgments}

Supported by the National Key R\&D Program of China with grant number 2018YFB1107700, National Key Basic Research Program of China with grant number 2015CB059900, National Natural Science Fund of China with grant number 51705013, Beijing Natural Science Foundation with grant number 3162019 and J170002.

\section{References}

[1] P.K. Bowen, W.H. Sillekens: JOM. 68, (2016) 1175.

[2] V. Manakari, G. Parande, M.Gupta: Metals. 7, (2017) 2.

[3] F.Witte: Acta Biomater. 6, (2010) 1680.

[4] M.P Staiger., A.M.Pietak, J.Huadmai, Dias G: Biomaterials. 27, (2006) 1728.

[5] Y.Meng, Q. Chen, S. Sugiyama, J. Yanagimoto: J. Mater. Process. Tech. 247, (2017) 192.

[6] A. Srinivasan, Y.D. Huang, C.L. Mendis, H. Dieringa, C. Blawert, K.U. Kainer, N.Hort: Mater. Sci. Forum. 765, (2013) 28.

[7] K.Z.Chong, T.S. Shih: Mater. Chem. Phys., 80, (2003) 191.

[8] H.P. Duan, C.W. Yan, F.H. Wang: Electrochim Acta, 52, (2007) 3785

[9] W.Y. Mu, Y. Han: Surf. Coat. Tech., 202, (2008) 4278.

[10] T. Homola, P. Dzik, M. Veselý, J. Kelar, M. Cernak; M. Weiter: ACS App. Mater. \& Inter., 8, (2016) 33562.
[11]A. Pardo, P. Casajús, M. Mohedano, A.E. Coy, F. Viejo, B. Torres: Appl. Surf. Sci., 255, (2009) 6968.

[12] X.X. Xi, A.V. Pogrebnyakov, S.Y. Xu, K. Chen, Y. Cui, E.C. Maertz, C.G. Zhuang, Q. Li, D.R. Lamborn, J M. Redwing: Physical, C 456, (2007) 22.

[13] A.I. Gorunov: Metallurgist. 61, (2017) 498.

[14] M.K.A.A. Razab, M.S. Jaafar, N.H. Abdullah, M.F.M. Amin, M. Mohamed: J. Russ. Laser Res. 37, (2016) 197.

[15] M. Obara, H. Yabe, Y. Hirayama, K. Yakahashi, K. Furusawa, F. Barnier: High-Power Laser Ablation III, International Society for Optics and Photonics, (2000) p.8.

[16]C. Shuai, Y. Zhou, X. Lin, Y.W. Yang, C.D. Gao, X. Shuai, H. Wu, X.Y. Liu, P. Wu, P. Feng: J. Mater. SciMater. M. 28, (2016) 13.

[17] K. Indira, C. Sylvie, W. Zhongke, Z. Hongyu: Procedia Engineering. 141, (2016) 63.

[18] M. J. Dutta, R. Galun, B.L. Mordike, I. Manna: Mat. Sci. Eng. A-Struct. 361, (2003) 119.

[19] G. Abbas, Z. Liu, P. Skeldon: Appl. Surf. Sci. 247, (2005) 347.

[20] L.F. Guo, T.M. Yue, H.C. Man: J. Mater. Sci. 40, (2005) 3531.

[21]Y. Gao, C. Wang, M. Yao, H. Liu: Mater. Corros. 58, (2007) 463.

[22] C.P. Ma, G. Peng, L. Nie, H.F. Liu, Y.C. Guan: Appl. Surf. Sci. 445, (2018) 211.

[23] Y.C. Guan, W. Zhou, H.Y. Zheng, Z.L. Li: Appl. Phys. A-Mater. 101, (2010) 339.

[24] D.C. Florian, M.A. Melia, F.W. Steuer, B.F. Briglia, M.K. Purzycki, J.R. Scully: Biointerphases. 12, (2017) 021003.

[25] L. Shi, Y. Huang, L. Yang, F. Feyerabend, C. Mendis, R. Wilumeit, K.U. Kainer, N. Hort: J. Mech. Behav. Biomed. 47, (2015) 38.

[26] B.L. Xiao, Q. Yang, J. Yang, W.G. Wang, G.M. Xie, Z.Y. Ma: J. Alloy. Compd. 509, (2011) 2879.

[27] X.Y. Fang, D.Q. Yi, J.F. Nie, X.J. Zhang, B. Wang, L.R. Xiao: J. Alloy. Compd. 470, (2009) 311.

[28] K. Liu, J.H. Zhang, H.Y. Lu, D.X. Tang, L.L. Rokhlin, F.M. Elkin, J. Meng: Mater. Design. 31, (2010) 210.

[29] J. Zhou, J. Xu, S. Huang, Z. Hu, X. Meng, X. Feng: Surf. Coat. Tech. 309, (2017) 212.

[30]L. Wang, J. Huang, J. Dong, Z. Li, Y. Wu: Weld. World. 61, (2017) 299.

[31] A. Srinivasan, Y. Huang, C.L. Mendis, C. Blawert, K.U. Kainer, N. Hort: Mat. Sci. Eng. A-Struct. 595, (2014) 224.

[32] Y. Liu, Z.X. Kang, L.L. Zhou, J.Y. Zhang, Y.Y. Li: Corros. Eng. Sci. Tech. 51, (2016) 256.

[33]X. Gu, Y. Zheng, Y. Cheng, S. Zhong, T. Xi: Biomaterials. 30, (2009) 484.

[34] Y. Zheng, X. Gu, Y. Xi, D. Chai: Acta Biomater. 6 (2010) 1783-1791.

(Received: June 25, 2018, Accepted: October 21, 2018) 